\title{
Analysis of Russian Trade Relations with Shanghai Cooperation Organization
}

\author{
Valeriy Smirnov ${ }^{1, *}$, Vasiliy Ashmarin ${ }^{1}$, Anatoliy Blokhintsev ${ }^{1}$, Elena Lyubovtseva ${ }^{1}$ and Elvira \\ Kuznetsova ${ }^{1}$ \\ ${ }^{1}$ Chuvash State University named after I.N. Ulyanova, Moskovsky prospekt, 15, 428015, Cheboksary, \\ Russia, \\ *Corresponding author
}

Keywords: Agglomeration, Import, Cluster Analysis, Trade Relations, Shanghai Cooperation Organization, Export.

Abstract: The subject of the study are the trade relations of Russia with the countries of the Shanghai Cooperation Organization (SCO) for goods and product groups of the Foreign Economic Activity Commodity Nomenclature (FEACN)of the Federal Customs Service of the Russian Federation. The aim of the paper is to identify clusters of countries, goods and commodity groups for imports to Russia and Russian exports. The article reveals the causes of SCO formation and recognizes its role in development of international trade cooperation. The study revealed match of clusters of SCO countries in terms of imports to Russia and Russian exports - India, China, Kazakhstan and Kyrgyzstan. Among the goods and commodity groups of imports to Russia there prevail: nuclear reactors, boilers, equipment and mechanical devices; organic chemical compounds; ores, slag and ash. Wide FEACN of Russian exports was revealed - mineral fuel, oil and products of their distillation; bituminous substances; mineral waxes; wood and products thereof; ferrous metals and others. Unlike imports the hierarchy of Russian exports in terms of goods and commodity groups is not stable.

\section{Introduction}

In the context of change of leaders of world economic activity and strengthening of global competition there is a growing need for alternative forms of international trade cooperation to the world trade organization (WTO). As a result of the Uruguay round of negotiations (1986-1994) and the General agreement on tariffs and trade (1947) there was established the WTO on January 1, 1995 to liberalize international trade and to regulate trade relations.

Negotiations on introduction of Russia to the WTO have been conducted for eighteen years (1993-2011). Russia became a WTO member on August 22, 2012. The main objectives of introduction of Russia to the WTO are as follows: getting the best conditions for the access of domestic products to foreign markets; resolving trade disputes through international mechanisms; attracting investments from outside, creating favorable climate for them and bringing legislation in line with WTO rules; increasing accessibility of the international arena for Russian investors; creation of favorable conditions for improvement of quality and competitiveness of Russian goods and services as a result of import growth; participation in formation of international trade rules taking into 
account national interests; improvement of the country's reputation as a full participant of international trade.

In the context of increased international trade competition Russia's possible preferences in the WTO were disputed by its main beneficiaries. The most difficult negotiations on Russia's accession to the WTO were conducted with the United States, the European Union and China on behalf of the projects "List of specific obligations for access to the services market" and "List of most-favored-nation exemptions" (1999). To resolve the disagreements Russia began to actively develop trade relations with the countries of the world in the format of international cooperation organizations SCO, the Eurasian economic community, BRICS (Brazil, Russia, India, China, South Africa) $[1,2]$.

\section{Literature Review}

SCO is an international organization founded in 2001 by the leaders of China, Russia, Kazakhstan, Tajikistan, Kyrgyzstan and Uzbekistan. According to article 1 of the SCO Charter the main objectives are to promote effective regional cooperation in trade and economic area and to promote comprehensive, balanced economic growth.

SCO is one of the last regional organizations that emerged in the new Millennium which implements the task of creating favorable trade relations [3]. The need for economic cooperation of SCO countries is due to the fact that through its channels the international organization can solve not only the problems of optimization of foreign economic activity of countries and trade relations but also significantly affect the economic and political processes in the region in full compliance with the principle of non-interfering the internal affairs and respect for national sovereignty.

SCO's economic impact on Russia is associated with the ability to fully load the capacity of the domestic industry and develop the national infrastructure, to open new markets for their products. Political - the beginning of a new world view of security that comprises such principles as mutual trust, disarmament and cooperation, a new stage in the multipolar world development [4].

\section{Method}

To determine the countries - strategic partners, priority products and product groups, there can be applied the method of cluster analysis, recognized in the world practice. Cluster analysis of Russia's trade relations with SCO countries includes assessment of cooperation by countries, goods and commodity groups in terms of 97 foreign economic activity commodity nomenclature (FEACN) codes.

Cluster analysis is a multi-dimensional statistical procedure for collecting of data containing information on objects sampling and ordering of objects of study in relatively homogenous groups. Cluster analysis makes it possible to develop a classification of objects or phenomena under study, to identify the main schemes of their grouping, to formulate hypotheses $[5,6]$.

Clustering process and result depend on the chosen method and means determination of distance measurement unit. The study applies a hierarchical method of cluster analysis the essence of which is to consistently combine smaller clusters into larger ones. Hierarchical agglomerative methods are characterized by sequential unification of the initial elements and reduction of the number of clusters. The procedure of cluster analysis involves combination of objects similar to each other into groups the distance between them is the smallest. There are different rules for determining the distance between clusters called the methods to join or link two clusters. To give greater weights to objects more distant from each other in the study we use a measure of distance - the "square of the Euclidean distance". 


\section{Result\&Analysis}

Cluster analysis of countries, goods and commodity groups in terms of import to Russia. To reduce competition of countries within clusters in terms of homogeneity of goods and product groups the measure of similarity between them should be minimal (the square of the Euclidean distance is maximal). Cluster analysis of countries in terms of import of goods and commodity groups to Russia the FEACN allowed to identify the following agglomerations (Table 1).

Table 1. Agglomeration (cluster) order of countries in terms of imports to Russia.

\begin{tabular}{ccc}
\hline & Cluster & Square of Euclidean distance \\
\hline India & China & $1.83041 \mathrm{E}+21$ \\
& Kazakhstan & $1.91664 \mathrm{E}+19$ \\
& Kyrgyzstan & $2.5531 \mathrm{E}+18$ \\
Kyrgyzstan & Uzbekistan & $7.25113 \mathrm{E}+17$ \\
& Pakistan & $4.64768 \mathrm{E}+16$ \\
& Tajikistan & $3.05741 \mathrm{E}+16$
\end{tabular}

Source: calculated in "SPSS Statistics" on the basis of data "Statistics of foreign trade of Russia. The Federal Customs Service of the Russian Federation”. URL: http://data.trendeconomy.EN (Accessed: 18.09.2019).

Cluster analysis revealed stable hierarchy of countries importing to Russia where China and India play a leading role. In the last decade of international trade relations the strategic partnership with China has become increasingly important for Russia. China has put enough effort into this. In 2015 in order to maintain "status quo" in trade relations with SCO countries China disagreed the admission of India and Pakistan into SCO.

Experts of the SCO Forum (2017) argued that bilateral contradictions between individual SCO member states (China and India) should not impede achievement of the general agreement and development of consensus decisions on key issues of trade relations. Expansion gives SCO a new dimension actualizing new challenges and opening up prospects for updating the formats of multilateral trade relations. The importance of the SCO Forum is determined by the advisory and expert mechanism to support foreign economic activity of countries.

Initiated by China the SCO plays a major role in creating favorable trade relations between the countries. Thanks to SCO and its active role positioning, China is fully realizing its export potential in the Central Asia. To maintain a leading role in Russia's import China is actively developing the "Economic belt of the great silk road" [7,8].

Cluster analysis of goods and commodity groups of trade cooperation between Russia and SCO countries allowed to identify priority imports of FEACN:

1)"01. Live animals (2018)" "84. Nuclear reactors, boilers, equipment and mechanical devices; their parts (2018)", "29. Organic chemicals (2018)" and "26. Ores, slag and ash (2018)";

2) "84. Nuclear reactors, boilers, equipment and mechanical devices; their parts (2018)", "84. Nuclear reactors, boilers, equipment and mechanical devices; their parts (2019-2020)" and " 85 . Electrical machinery and equipment, parts thereof; sound recording and reproducing devices, devices for recording and reproducing television image and sound, parts and accessories thereof (2018)";

3) "26. Ores, slag and ash (2018)" and "72. Ferrous metals (2018)"; 
4) "29. Organic chemical compounds (2018)" and "64. Shoes, gaiters and similar articles; their details (2019)".

The results of cluster analysis indicate a stable hierarchy of clusters of goods and commodity groups on imports " 84 . Nuclear reactors, boilers, equipment and mechanical devices; their parts (2018-2020)"'.

Cluster analysis of countries, goods and commodity groups in terms of Russian exports. Cluster analysis of the countries of the Russian trade cooperation on the Russian export of goods and FEACN commodity groups allowed to reveal the following agglomerations (Table 2).

Table 2. Agglomeration (cluster) order of countries in terms of imports to Russia.

\begin{tabular}{lcc}
\hline & Cluster & Square of Euclidean distance \\
\hline India & Kyrgyzstan & $3.51051 \mathrm{E}+35$ \\
& Kazakhstan & $2.48933 \mathrm{E}+33$ \\
& China & $4.53991 \mathrm{E}+21$ \\
Kyrgyzstan & Uzbekistan & $2.66102 \mathrm{E}+18$ \\
& Pakistan & $1.27962 \mathrm{E}+18$
\end{tabular}

Source: calculated in "SPSS Statistics" on the basis of data "Statistics of foreign trade of Russia. The Federal Customs Service of the Russian Federation" URL: http://data.trendeconomy.EN (Accessed: 18.09.2019).

Cluster analysis revealed absence of a stable hierarchy of Russian export countries. For Russian exports the "Chinese concept" of development remains significant. It will help to overcome the prolonged global stagnation and ensure stability of economic growth, including as a result of trade, investment and interbank economic cooperation, transport and logistics cooperation and energy cooperation.

In turn, the loss of China's position relative to India, Kyrgyzstan and Kazakhstan is due to significant differences in the economic potential of SCO members. China's desire to develop global Eurasian integration can enhance its position and strengthen the impact of the SSO on the world economy.

Cluster analysis of goods and commodity groups for Russian exports revealed FEACN priorities:

1) "01. Live animals (2018)", "27. Mineral fuel, oil and products of their distillation; bituminous substances; mineral waxes (2018)", "44. Wood and wood products; charcoal (2018)", "03. Fish and crustaceans, clams and other aquatic invertebrates (2018)", "72. Ferrous metals (2018)" and "71. Natural or cultured pearls, precious or semi-precious stones, precious metals, metals clad with precious metals, and articles thereof; bijouterie; coins (2018)";

2) "03. Fish and crustaceans, clams and other aquatic invertebrates (2018)", "84. Nuclear reactors, boilers, equipment and mechanical devices; parts thereof (2018)" and "74. Copper and copper products (2020)";

3) "27. Mineral fuels, mineral oils and products of their distillation; bituminous substances; mineral waxes (2018-2020)"

4) "74. Copper and copper products (2020)" and "SS. Secret code (2018)".

The results of cluster analysis indicate absence of a hierarchy of products and product groups by FEACN. In the future the leading position in goods and commodity groups of Russian commodity exports will remain for " 27 . Mineral fuel, oil and products of their distillation; bituminous substances; mineral waxes (2018-2020)". 


\section{Discussion of Results}

Decline in the pace of world trade and increased global competition have strengthened the role of consolidating forms of international trade cooperation. Along with the WTO alternative forms of international trade cooperation began to emerge. Russia began to actively develop trade relations with the countries of the world in the format of SCO, the Eurasian economic community and BRICS which have become a necessary part of Russia's trade relations with WTO countries.

As a result of cluster analysis of trade relations between Russia and SCO countries the leaders in imports to Russia and Russian exports - India, China, Kazakhstan and Kyrgyzstan - have been identified. The main imports to Russia for FEACN goods and commodity groups are "84. Nuclear reactors, boilers, equipment and mechanical devices; their parts (2018)", "29. Organic chemicals (2018)" and "26. Ores, slag and ash (2018)".

The basis of Russian exports - "27. Mineral fuel, oil and products of their distillation; bituminous substances; mineral waxes (2018)", "44. Wood and wood products; charcoal (2018)", "72. Ferrous metals (2018)", "03. Fish and crustaceans, clams and other aquatic invertebrates (2018)", "71. Natural or cultured pearls, precious or semi-precious stones, precious metals, metals clad with precious metals and articles thereof; bijouterie; coins (2018)".

\section{Conclusion}

Cluster analysis of Russia's trade relations with SCO countries revealed the potential of trade and economic cooperation, indicated the directions of promoting balanced economic growth and development of trade relations for the relevant goods and FEACN product groups. In contrast to the established stable hierarchy of importing countries the hierarchy of Russian exports is not stable due to diversification of export goods and product groups.

Russia's fairly high dependence on trade cooperation with China limits the possibilities for further diversification of Russian exports within the limits of " 27 . Mineral fuel, oil and products of their distillation; bituminous substances; mineral waxes (2018-2020)". As a result of cluster analysis of the potential of Russia's international trade cooperation with SCO countries it has been determined that Russia's role as a FEACN supplier has strengthened " 27 Mineral fuel, oil and products of their distillation; bituminous substances; mineral waxes (2018-2020)".

\section{References}

[1] V. Smirnov, V. Semenov, E. Kadyshev, A. Suchkova, A. Zakharova. The Analysis of trade relations Of Russia with Germany and France. Proceedings of the International Scientific-Practical Conference "Business Cooperation as a Resource of Sustainable Economic Development and Investment Attraction" (ISPCBC 2019). Advances in Economics, Business and Management Research, 2019: 308-312. https://www.atlantis-press.com/article/125914529

[2] V. V. Smirnov, D. G. Osipov, A. A. Babaeva, E. V. Grigorieva, E. F. Perfilova. Parity of innovation and digital economy in the Russian management system. Modern Management Trends and the Digital Economy: from Regional Development to Global Economic Growth. (MTDE 2019). Advances in Economics, Business and Management Research, 2019: 22-27. https://doi.org/10.2991/mtde-19.2019.5

[3] M. Al-Qahtani. The Shanghai Cooperation Organization and the Law of International Organizations. Chinese Journal of International Law, 2006, 5(1): 129-147. https://doi.org/10.1093/chinesejil/jml012. 
[4] M. S. Yi. Yin. Analysing Regionalism within International Law and Relations: The Shanghai Cooperation Organisation as a Grossraum? Chinese Journal of International Law, 2014, 13(4): 819-877. https://doi.org/10.1093/chinesejil/jmu044.

[5] A. Adolfsson, M. Ackerman, N. C. Brownstein. To cluster, or not to cluster: An analysis of clusterability methods". Pattern Recognition, 2019, 88: 13-26. https://doi.org/10.1016/j.patcog.2018.10.026

[6] L. P. Fávero, P. Belfiore. Chapter 11: Cluster Analysis. Data Science for Business and Decision Making, 2019: 311-382. https://doi.org/10.1016/B978-0-12-811216-8.00011-2

[7] Y. Yang, M. Fan. Analysis of the spatial-temporal differences and fairness of the regional energy ecological footprint of the Silk Road Economic Belt (China Section). Journal of Cleaner Production, 2019, 215: 1246-1261. https://doi.org/10.1016/j.jclepro.2019.01.170

[8] Y. Yang, N. Hu. The spatial and temporal evolution of coordinated ecological and socioeconomic development in the provinces along the Silk Road Economic Belt in China. Sustainable Cities and Society, 47, May 2019, Article 101466. https://doi.org/10.1016/j.scs.2019.101466 